Journal of Animal and Veterinary Advances 9 (24): 3104-3108, 2010

ISSN: $1680-5593$

(C) Medwell Journals, 2010

\title{
Effects of Diets Containing Monensin, Garlic Oil or Turmeric Powder on Ruminal and Blood Metabolite Responses of Sheep
}

\author{
A.A. Hodjatpanah, M. Danesh Msegaran and A.R. Vakili \\ Excellence Center for Animal Science, Department of Animal Science, \\ Faculty of Agriculture, Ferdowsi University of Mashhad, \\ P.O. Box 91775-1163, Mashhad, Iran
}

\begin{abstract}
The aim of the present study was to evaluate the effect of diets containing Garlic oil (GA), Turmeric powder (TU) or Monensin (MO) on ruminal $\mathrm{pH}$, ammonia nitrogen concentration and various blood metabolites concentrations and blood gases in sheep. Four rumen cannulated Baloochi sheep were used as a $4 \times 4$ Latin square design with 4 periods and 28 day each. Treatments were: basal diet including $55 \%$ concentrate and $45 \%$ dry alfalfa hay (control), basal diet+GA ( $420 \mathrm{mg} /$ sheep/day), basal diet+TU ( $20 \mathrm{~g} / \mathrm{sheep} /$ day $)$ and basal $\operatorname{diet}+\mathrm{MO}(200 \mathrm{mg} / \mathrm{sheep} /$ day $)$. Diets were fed once daily ad libitum. Ruminal fluid samples were collected before the feeding and every $15 \mathrm{~min}$ until $8 \mathrm{~h}$ post feeding at days 25 of the each experimental period. Blood samples were taken from jugular vein before the feeding and 2,4 and $6 \mathrm{~h}$ post feeding at day 27 and before the feeding and $6 \mathrm{~h}$ post feeding at day 28 of each period of the experiment. Adding GA, TU or MO to the basal diet had no significant effect on mean and minimum of ruminal $\mathrm{pH}$ and ammonia nitrogen concentration ( $\mathrm{p}>0.05$ ) while maximum value of ruminal $\mathrm{pH}$ was significantly decreased by $\mathrm{MO}$ and $\mathrm{TU}(\mathrm{p}<0.05)$. The experimental treatments did not change the plasma concentrations of glucose and urea-N ( $<<0.05)$. Supplementation with $M O$ caused a significant increase in jugular blood partial pressure of $\mathrm{O}_{2}$ and tended to raise blood percent $\mathrm{O}_{2}$ saturation $(\mathrm{p}<0.05)$.
\end{abstract}

$\underline{\text { Key words: Garlic oil, turmeric powder, monensin, ruminal fermentation, plasma concentration, significant }}$

\section{INTRODUCTION}

During ruminal fermentation a part of consumed energy and protein are excreted (as methane and ammonia nitrogen, respectively) without utilization by rumen microflora or host animal (Busquet et al., 2006). For this reason, ruminant nutritionists have suggested optimizing diet formulation and using feed additives. Supplementation diets with antibiotics growth promoters such as monensin and lasalocid diminish losses of energy and nitrogen (Ipharraguerre and Clark, 2003). However, the use of antibiotics as feed additives has been banned in many countries due to the risk of appearance of antibiotic residues in milk and meat and development of multi-drug bacteria (Russell and Houlihan, 2003). For many years, plant extracts have been used for remediation of diseases and also as food preservatives because of their antimicrobial characteristics (Davidson and Naidu, 2000). Results of previous studies indicated that extract of some plants can be appropriate alternatives for antibiotics growth promoters (Calsamiglia et al., 2006). Garlic oil possesses different curative properties such as, antiparasitic, antioxidant, anti-inflammatory and hypoglycemic. Garlic oil lessened the proportion of acetate and increased proportion of propionate and butyrate in some in vitro studies (Cardozo et al., 2004; Busquet et al., 2005a-c). Moreover, it reduced methane production under in vitro condition (Chiquette and Benchaar, 2005). However, there is limited information about the effects of garlic oil on rumianl fermentation using in vivo exprimments (Yang et al., 2007; Chaves et al., 2008).

A large number of researches have demonstrated different biological properties of turmeric including antiinflammatory (Srimal and Dhawan, 1973), antimicrobial (Lutomski et al., 1974) and hypoglycemic (Arun and Nalini, 2002). To the knowledge, there is no information on the effect of turmeric on ruminal fermentation when it included in ruminant ration. The aim of this study was to assess the effects of diets containing Garlic oil (GA), Turmeric powder (TU) or Monensin (MO) on ruminal $\mathrm{pH}$, ammonia nitrogen concentration $\left(\mathrm{NH}_{3}-\mathrm{N}\right)$ and various blood plasma metabolites including glucose and urea- $\mathrm{N}$ concentrations and

Corresponding Author: M. Danesh Mesgaran, Excellence Center for Animal Science, Department of Animal Science, Faculty of Agriculture, Ferdowsi University of Mashhad, P.O. Box 91775-1163, Mashhad, Iran 
blood gases including partial pressure of $\mathrm{O}_{2}$, partial pressure of $\mathrm{CO}_{2}$ and percent $\mathrm{O}_{2}$ saturation in sheep.

\section{MATERIALS AND METHODS}

Four rumen cannulated Baloochi sheep were used in a $4 \times 4$ Latin square design with 4 periods (each period of 28 days). Sheep were fed a basal diet (Table 1) without supplementation (control) or a basal diet supplemented with GA ( $420 \mathrm{mg} / \mathrm{sheep} \mathrm{per/day),} \mathrm{TU} \mathrm{(20} \mathrm{g/lamb} \mathrm{per/day)}$ or MO (200 mg/sheep per/day). Diets consisted of $55 \%$ concentrate and $45 \%$ dry alfalfa hay (Table 1 ) and were fed once daily ad libitum. The animals were assigned to individual metabolical cages $(0.5 \times 1.2 \times 1 \mathrm{~m})$ and had free access to salt and fresh water throughout the experiment. Each period included 21 days of adaptation and 7 days of sample collection of rumianl fluid and blood. Ruminal fluid samples $(10 \mathrm{~mL})$ were collected on day 25 before the feeding and every $15 \mathrm{~min}$ until $8 \mathrm{~h}$ post feeding. Samples of ruminal contents were strained through four layers of cheesecloth and $\mathrm{pH}$ was measured using a $\mathrm{pH}$ meter (Metrohm 744, Switzerland). A volume of $10 \mathrm{~mL}$ of the filtrated ruminal fluid acidified with $10 \mathrm{~mL}$ of HCL $0.2 \mathrm{~N}$ and stored for later determination of $\mathrm{NH}_{3}-\mathrm{N}$ concentration. Ruminal $\mathrm{NH}_{3}-\mathrm{N}$ was determined using distillation method (Kjeltec Auto 1030 Analyzer Tecator, tecator, Hoganas, Sweden).

On day 27, Blood samples were taken from jugular vein before the feeding, 2, 4 and $6 \mathrm{~h}$ post feeding with heparinized syringe. Samples were centrifuged $(3500 \times \mathrm{g}$ for $15 \mathrm{~min}$ at $4^{\circ} \mathrm{C}$ ) and collected plasma was kept frozen at $-20^{\circ} \mathrm{C}$ for further analysis. Plasma glucose and urea-N concentrations were determined by an auto-analyzer (Alcyon 300i Abbott, USA). In order to determine blood gases and $\mathrm{pH}$, jugular blood samples were collected using heparinized syringes before and $4 \mathrm{~h}$ after the feeding on

Table 1: Ingredients and chemical composition of the basal diet fed to sheep (Percentage of DM)

\begin{tabular}{|c|c|}
\hline Item & Percentage \\
\hline \multicolumn{2}{|l|}{ Ingredients (\% of DM) } \\
\hline Alfalfa & 45.0 \\
\hline Corn grain & 15.0 \\
\hline Barley grain & 19.0 \\
\hline Cottonseed meal & 6.0 \\
\hline Soybean meal & 4.0 \\
\hline Sugar beet pulp & 3.0 \\
\hline Wheat bran & 5.0 \\
\hline Calcium carbonate & 1.0 \\
\hline Salt & 1.0 \\
\hline Vitamin-mineral mix $^{1}$ & 1.0 \\
\hline $\mathrm{CP}\left(\mathrm{g} \mathrm{kg}^{-1} \mathrm{DM}\right)$ & 155.0 \\
\hline $\mathrm{NDF}\left(\mathrm{g} \mathrm{kg}^{-1} \mathrm{DM}\right)$ & 289.0 \\
\hline ME (Mcal kg $\left.{ }^{-1} \mathrm{DM}\right)$ & 2.8 \\
\hline
\end{tabular}

day 28. The syringes were chilled in an ice bath immediately and transported to the laboratory within $1 \mathrm{~h}$. Blood partial pressure of gaseous $\mathrm{O}_{2}$ dissolved in blood $\left(\mathrm{pO}_{2}\right)$, partial pressure of $\mathrm{CO}_{2}\left(\mathrm{pCO}_{2}\right)$ and percent $\mathrm{O}_{2}$ saturation were measured by a $\mathrm{pH} / \mathrm{Blood}$ Gas Analyzer (Stat Profile pHOx Plus blood analyzer, Nova Biomedical, USA). Data were applied to the mixed model of SAS (version 9.1; SAS Institute Inc., Cary, NC) with the following statistical model of:

$$
\mathrm{Y}_{\mathrm{ij} \mathrm{klm}}=\mu+\mathrm{A}_{\mathrm{i}}+\mathrm{B}_{\mathrm{j}}+\mathrm{C}_{\mathrm{k}}+\mathrm{D}_{1}+(\mathrm{AD})_{\mathrm{i} 1}+\varepsilon_{\mathrm{ijklm}}
$$

Where:

$\mathrm{Y}_{\mathrm{ijklm}}=$ The depndent variable

$\mu \quad=$ The overral mean

$\mathrm{A}_{\mathrm{i}} \quad=$ The treatment effect

$\mathrm{B}_{\mathrm{j}} \quad=$ The period effect

$\mathrm{C}_{\mathrm{k}}=$ The random effect of animal within treatments

$\mathrm{D}_{1} \quad=$ The sampling time effect

$(\mathrm{AD})_{\mathrm{i} 1}=$ The interaction effect of treatment and sampling time

$\varepsilon_{\text {jklm }}=$ The residual error

The sampling time was included in the model as repeated measurement by using compound symmetry. Differences between least squares means were considered significant at $\mathrm{p}<0.05$, using PDIFF in the LSMEANS statement.

\section{RESULTS AND DISCUSSION}

Under present study conditions, mean of ruminal $\mathrm{pH}$ was not affected by GA, TU or MO (Table 2). Similarly, the lowest ruminal $\mathrm{pH}$ value was the same among the treatments (Table 2). However, the highest ruminal $\mathrm{pH}$ value was reduced in sheep fed TU or MO compared with those fed the control diet. These results are consistent with some studies (Chaves et al., 2008) where ruminal pH of sheep were not affected by the feeding rations supplemented with GA and the results obtained by Meyer et al. (2009) in which addition of MO or a blend of plant extracts in diet were not influenced the ruminal $\mathrm{pH}$ of steers. Yang et al. (2007) reported no significant changes in the mean, maximum and minimum of ruminal $\mathrm{pH}$ of dairy cows fed diets containing $\mathrm{MO}$ or GA. Furthermore, in some other studies $\mathrm{MO}$ did not alter ruminal $\mathrm{pH}$ of dairy cows (Ramanzin et al., 1997; Broderick, 2004). In contrast, a reduction in ruminal $\mathrm{pH}$ with a blend of plant extracts supplementation was reported by Benchaar et al. (2007) and Devant et al. (2007). The discrepancies among studies could be due to the type of diets and species used (Meyer et al., 2009). 
Table 2: Ruminal $\mathrm{pH}$ and ammonia nitrogen concentration $\left(\mathrm{NH}_{3}-\mathrm{N}\right)$ of sheep fed Basal Diet (BD) or plus Garlic oil (GA), Turmeric powder (TU) or monensin (mo)

\begin{tabular}{|c|c|c|c|c|c|c|}
\hline \multirow[b]{2}{*}{ Item } & \multicolumn{4}{|c|}{ Treatments } & \multirow[b]{2}{*}{ SEM } & \multirow[b]{2}{*}{$\mathrm{p}$-value } \\
\hline & $\mathrm{BD}$ & $\mathrm{BD}+\mathrm{GA}$ & $\mathrm{BBD}+\mathrm{TU}$ & $\mathrm{BD}+\mathrm{MO}$ & & \\
\hline \multicolumn{7}{|l|}{ pH } \\
\hline Mean & 6.34 & 6.11 & 6.22 & 6.28 & 0.12 & 0.32 \\
\hline Minimum & 5.67 & 5.48 & 5.51 & 5.58 & 0.12 & 0.72 \\
\hline Maximum & $7.48^{\mathrm{a}}$ & $7.27^{\mathrm{ab}}$ & $7.18^{\mathrm{bc}}$ & $7.01^{\mathrm{c}}$ & 0.11 & 0.04 \\
\hline $\begin{array}{l}\mathrm{N}-\mathrm{NH}_{3} \\
\left(\mathrm{mg} \mathrm{dL}{ }^{-1}\right)\end{array}$ & 18.74 & 22.41 & 17.73 & 18.51 & 2.72 & 0.31 \\
\hline
\end{tabular}

${ }^{a-c}$ Means within a row with different superscripts differ $(\mathrm{p}<0.05)$

In this experiment, supplementing of basal diet with GA, TU or MO did not affect $(\mathrm{p}>0.05)$ concentration of ruminal $\mathrm{NH}_{3}-\mathrm{N}$ (Table 2 ). This would agree with the results of Chaves et al. (2008) who reported that the addition of $\mathrm{GA}$ in the ration had no influence on $\mathrm{NH}_{3}-\mathrm{N}$ concentration in the rumen of sheep. Yang et al. (2007) observed no effect of GA and Mo on the ruminal $\mathrm{NH}_{3}-\mathrm{N}$ concentration of lactating cows. No change in $\mathrm{NH}_{3}-\mathrm{N}$ concentration in ruminal fluid by $\mathrm{MO}$ was also reported by the results of previous studies (Ramanzin et al., 1997; Broderick, 2004). Furthermore, in some in vitro studies a mixture of palnt extract had no significant effect on $\mathrm{NH}_{3}-\mathrm{N}$ concentration (Busquet et al., 2005c; Castillejos et al., 2006). Results of Cardozo et al. (2004) indicated a reduction in $\mathrm{NH}_{3}-\mathrm{N}$ concentration when GA was incubated in a continuous culture. Differences between results could be attributed to the ability of ruminal bacteria for adaptation to plant extract in long term studies after few days (Cardozo et al., 2004; Busquet et al., 2005c). Moreover, effects of plant extract could be varied according to the type and the plant originated (Cardozo et al., 2006).

Data of plasma glucose and urea-N concentrations at pre and post feeding are shown in Table 3 . Concentrations of glucose and urea- $\mathrm{N}$ in plasma were not influenced by additives treatments $(\mathrm{p}>0.05)$. These results confirmed the finding of Chaves et al. (2008) who reported no difference in serum glucose concentration of growing lambs fed diets supplemented with GA compared with control. Addition a specific mixture of essential oils in ration of periparturient and early lactation cows had no significant effect on plasma glucose and urea-nitrogen concentration (Tassoul and Shaver, 2009). Broderick (2004) reported that the adding of MO to the diet had no effect on blood urea-N concentration of dairy cows, although, plasma glucose tended to be significant.

In a earlier study (Brown and Hogue, 1987) plasma glucose concentration was not different among goats fed diet containing $\mathrm{MO}$ or control diet. Similar results were achieved in other studies (Duff et al., 1994; Petersson-Wolfe et al., 2007). There is no information about the effect of turmeric powder on glucose and
Table 3: Blood plasma glucose and urea-N concentration of sheep fed Basal Diet (BD) or plus Garlic oil (GA), Turmeric powder (TU) or monensin (mo)

$$
\text { Treatments }
$$

Item $\begin{array}{llllll}\mathrm{BD} & \mathrm{BD}+\mathrm{GA} & \mathrm{BD}+\mathrm{TU} & \mathrm{BD}+\mathrm{MO} & \mathrm{SEM} & \mathrm{p} \text {-value }\end{array}$

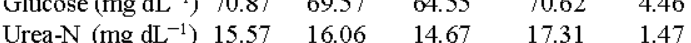

Table 4: Jugular blood $\mathrm{pH}$, partial pressure of $\mathrm{O}_{2}\left(\mathrm{pO}_{2}\right)$, partial pressure of $\mathrm{CO}_{2}\left(\mathrm{pCO}_{2}\right)$ and percent $\mathrm{O}_{2}$ saturation of sheep fed fed Basal Diet (BD) or plus Garlic oil (GA), Turmeric powder (TU) or Monensin (mo)

\begin{tabular}{|c|c|c|c|c|c|c|}
\hline \multirow[b]{2}{*}{ Item } & \multicolumn{4}{|c|}{ Treatments } & \multirow[b]{2}{*}{ SEM } & \multirow[b]{2}{*}{$\mathrm{p}$-value } \\
\hline & $\mathrm{BD}$ & $\mathrm{BD}+\mathrm{GA}$ & $\mathrm{BD}+\mathrm{TU}$ & $\mathrm{BD}+\mathrm{MO}$ & & \\
\hline $\mathrm{pH}$ & 7.405 & 7.429 & 7.402 & 7.420 & 0.02 & 0.79 \\
\hline $\mathrm{pO}_{2}(\mathrm{~mm} \mathrm{Hg})$ & $34.510^{\mathrm{a}}$ & $36.220^{\mathrm{ab}}$ & $31.400^{\mathrm{a}}$ & $39.360^{b}$ & 1.52 & 0.01 \\
\hline $\mathrm{pCO}_{2}(\mathrm{~mm} \mathrm{Hg})$ & 39.670 & 39.740 & 39.000 & 38.510 & 1.68 & 0.94 \\
\hline $\mathrm{O}_{2}$ saturation $(\%)$ & 63.950 & 67.980 & 63.600 & 70.570 & 3.50 & 0.08 \\
\hline
\end{tabular}

${ }^{a-c}$ Means within a row with different superscripts differ $(p<0.05)$

urea-N in ruminants. Mehala and Moorthy (2008) demonstrated that supplementation turmeric in broiler chicken diets did not alter serum glucose concentration significantly. However, administration of turmeric or its active compound, curcumin, to diabetic rats diminished blood sugar (Arun and Nalini, 2002).

Blood $\mathrm{pH}$ varies from 7.40-7.42 and did not differ among the animal fed the present experimental diets (Table 4). Diet supplemented by $\mathrm{MO}$ increased $\mathrm{pO}_{2}$ in comparison with the control $(\mathrm{p}<0.05)$ while $\mathrm{pCO}_{2}$ was not impacted by the experimental diets $(\mathrm{p}>0.05$ ). In addition, percent $\mathrm{O}_{2}$ saturation tended to increase in sheep fed $\mathrm{MO}$ $(\mathrm{p}>0.10)$. Blood gas analysis is a clinical tool for determining acid-base status in animal (Bouda et al., 2000). According to the study of Hernandez et al. (2009) plant extracts could change blood acid-base status. They reported that a blend of plant extracts increased blood $\mathrm{pH}$ of growing bull calves fed a high grain diet. The results are consistent with the finding of Candanosa et al. (2008), who observed no change in blood $\mathrm{pH}$ and $\mathrm{pCO}_{2}$ in sheep fed MO. Ionophers might affect acid/base balance and cellular activity through regulating ion translocation across cellular membrane and therefore may lead to a change in atmospheric and also tissue respiration (Yang et al., 2003).

\section{CONCLUSION}

In this study, present supplementation of the basal diet with GA, TU or MO has sicnificant effect on maximal rumen $\mathrm{pH}$ evaluated during $8 \mathrm{~h}$ post feeding. The concentration of blood plasma metabolites are not altered by the present treatments. Addition of $\mathrm{MO}$ to the basal diet elevated $\mathrm{pO}_{2}$ in the blood. Moreover there is a tendency to increase in blood percent $\mathrm{O}_{2}$ saturation of 
sheep fed basal diet plus MO. Present results indicate that both GA and TU have a potential to change the rumen and blood metabolite responses. However, there is a need to evaluate the effects under in vivo experimental condition using higher concentration of these additives.

\section{REFERENCES}

Arun, N. and N. Nalini, 2002. Efficacy of turmeric on blood sugar and polyol pathway in diabetic albino rats. Plant Foods Hum. Nutr., 57: 41-52.

Benchaar, C., H.V. Petit, R. Berthiaume, D.R. Ouellet, J. Chiquette and P.V. Chouinard, 2007. Effects of essential oils on digestion, ruminal fermentation, ruminal microbial populations, milk production and milk composition in dairy cows fed alfalfa silage or corn silage. J. Dairy Sci., 90: 886-897.

Bouda, J., J.L. Daivalos-Flores, L. Nuniez-Ochoa, L. Paasch-Martinez and G.F. Quiroz-Rocha, 2000. Blood acid-base and serum electrolyte values in red deer (Cervus elaphus). Can. J. Vet. Res., 64: 222-225.

Broderick, G.A., 2004. Effect of low level monensin supplementation on the production of dairy cows fed alfalfa silage. J. Dairy Sci., 87: 359-368.

Brown, D.L. and D.E. Hogue, 1987. Effects of feeding monensin to lactating goats: Acetyl coenzyme a carboxylase, hormone-sensitive lipase, plasma glucose and circulating hormones. J. Dairy Sci., 70: $823-830$.

Busquet, M., S. Calsamiglia, A. Ferret and C. Kamel, 2006. Plant extracts affect in vitro rumen microbial fermentation. J. Dairy Sci., 89: 761-771.

Busquet, M., S. Calsamiglia, A. Ferret, M.D. Carro and C. Kame1, 2005a. Effect of garlic oil and four of its compounds on rumen microbial fermentation. J. Dairy Sci., 88: 4393-4404.

Busquet, M., S. Calsamiglia, A. Ferret, P.W. Cardozo and C. Kamel, 2005b. Effects of cinnamaldehyde and garlic oil on rumen microbial fermentation in a dual flow continuous culture. J. Dairy Sci., 88: 2508-2516.

Busquet, M., S. Calsamiglia, A. Ferret and C. Kamel, 2005c. Screening for the effects of natural plant extracts and secondary plant metabolites on rumen microbial fermentation in continuous culture. Anim. Feed Sci. Technol., 123-124: 597-613.

Calsamiglia, S., L. Castillejos and M. Busquet, 2006. Alternatives to Antimicrobial Growth Promoters in Cattle. In: Recent Advances in Animal Nutrition, Garnsworthy, P.C. and J. Wiseman (Eds.). Nottingham University Press, Nottingham, UK.
Candanosa, E., A. Villa-Godoy, D.A. Castillo and G.D. Mendoza, 2008. Effect of monensin, virginiamycin and sodium bicarbonate on ruimanl fermentation and acid-base status in sheep. J. Anim. Vet. Adv., 7: 184-189.

Cardozo, P.W., S. Calsamiglia, A. Ferret and C. Kamel, 2004. Effects of plant extract on ruminal protein degradation and fermentation profiles in continuous culture. J. Anim. Sci., 82: 3230-3236.

Cardozo, P.W., S. Calsamiglia, A. Ferret and C. Kamel, 2006. Effects of alfalfa extract, anise, capsicum and a mixture of cinnamaldehyde and eugenol on ruminal fermentation and protein degradation in beef hrifers fed a high-concentrate diet. J. Anim. Sci., 84: 2801-2808.

Castillejos, L., S. Calsamiglia and A. Ferret, 2006. Effect of essential oil active compounds on rumen microbial fermentation and nutrient flow in in vitro systems. J. Dairy Sci., 89: 2649-2658.

Chaves, A.V., K. Stanford, M.E.R. Dugan, L.L. Gibson, T.A. McAllister, F. van Herk and C. Benchaar, 2008. Effects of cinnamaldehyde, garlic and juniper berry essential oils on rumen fermentation, blood metabolites, growth performance and carcass characteristics of growing lambs. Livest. Sci., 117: $215-224$.

Chiquette, J. and C. Benchaar, 2005. Effects of different dose levels of essential oils compounds on in vitro methane production by mixed ruminal bacteria. J. Dairy Sci., 83: 306-306.

Davidson, P.M. and A.S. Naidu, 2000. Phyto-Phenols. In: Natural Food Antimicrobial System, Naidu, A.S. (Ed.). CRC Press, Boca Raton, FL., ISBN: 8493-2047, pp: 265-294.

Devant, M., A. Anglada and A. Bach, 2007. Effects of plant extract supplementation on rumen fermentation and metabolism in young Holstein bulls consuming high levels of concentrate. Anim. Feed. Sci. Technol., 137: 46-57.

Duff, G.C., M.L. Galyean, M.E. Branine and D.M. Hallford, 1994. Effects of lasalocid and monensin plus tylosin on serum metabolic hormones and clinical chemistry profiles of beef steers fed $90 \%$ concentrate diets. J. Anim. Sci., 72: 1049-1058.

Hernandez, J., J.L. Benedito, P. Vazquez, V. Pereira, J. Mendez, J. Sotillo and C. Castillo, 2009. Supplementation with plant extracts (carvacrol, cinnamaldehyde and capsaicin): Its effects on acidbase status and productive performance in growing/finishing bull calves. Berl. Munch. Tierarztl. Wochenschr., 122: 93-99. 
Ipharraguerre, I.R. and J.H. Clark, 2003. Usefulness of ionophores for lactating dairy cows: A review. Anim. Feed Sci. Technol., 106: 39-57.

Lutomski, J., B. Kedzia and W. Debska, 1974. Effect of an alcohol extract and of active ingredients from Curcuma longa on bacteria and fungi. Planta Medica, 26: 9-19.

Mehala, C. and M. Moorthy, 2008. Effect of aloe vera and Curcuma longa (Turmeric) on carcass characteristics and biochemical parameters of broilers. Int. J. Poult. Sci., 7: 857-861.

Meyer, N.F., G.E. Erickson, T.J. Klopfenstein, M.A. Greenquist, M.K. Luebbe, P. Williams and M.A. Engstrom, 2009. Effect of essential oils, tylosin and monensin on finishing steer performance, carcass characteristics, liver abscesses, ruminal fermentation and digestibility. J. Anim. Sci., 87: 2346-2354.

Petersson-Wolfe, C.S., K.E. Leslie, T. Osborne, B.W. McBride and R. Bagg et al., 2007. Effect of delivery method of monensin on dry matter intake, body condition score and metabolic parameters in transition dairy cows. J. Dairy Sci., 90: 1870-1879.
Ramanzin, M., L. Bailoni, S. Schiavon and G. Bittante, 1997. Effect of monensin on milk production and efficiency of dairy cows fed two diets differing in forage to concentrate ratios. J. Dairy Sci., 80: 1136-1142.

Russell, J.B. and A.J. Houlihan, 2003. Ionophore resistance of ruminal bacteria and its potential impact on human health. FEMS Microbiol. Rev., 27: 65-74.

Srimal, R.C. and B.N. Dhawan, 1973. Pharmacology of diferuloyl methane (curcumin, anonsteroidal anti-inflammatory agent). J. Pharm. Pharmacol., 25: $447-452$.

Tassoul, M.D. and R.D. Shaver, 2009. Effect of a mixture of supplemental dietary plant essential oils on performance of periparturient and early lactation dairy cows. J. Dairy Sci., 92: 1734-1740.

Yang, C.M.J., C.T. Chang, S.C. Huang and T. Chang, 2003. Effect of lasalocid on growth, blood gases and nutrient utilization in dairy goats fed a high forage, low protein diet. J. Dairy Sci., 86: 3967-3971.

Yang, W.Z., C. Benchaar, B.N. Ametaj, A.V. Chaves, M.L. He and T.A. McAllister, 2007. Effects of garlic and juniper berry essential oils on ruminal fermentation and on the site and extent of digestion in lactating cows. J. Dairy Sci., 90: 5671-5681. 